Mini Review

\title{
Subungual osteochondroma: review of the literature
}

\begin{abstract}
Introduction: Subungual osteochondroma are benign tumors of the sub or periungual region, causing lift, ulceration and deformity at that level.
\end{abstract}

Methods: Retrospective, descriptive, observational and transversal study, based on review of records with histopathological result of osteochondroma from 2001 to 2014

Results: Pathological assessment featured 4 osteochondromas corresponded to the subungual presentation, with an equal gender distribution of $1: 1$, an average age of 9.5 years, right:left ratio of $3: 1$, the 4th finger was the most affected.

Conclusion: Subungual osteochondroma has an incidence of $8.5 \%$ of all osteochondromas, there is important the detection of this benign tumor, its difference with subungual exostosis, doing emphasis at the importance of confirm it with histopatology studie.

Keywords: Osteochondroma, Sungungual, Incidence
Volume 8 Issue 5 - 2017

Tamayo Pacho Franklin,' Montero Quijano Miguel,' Mora Ríos Félix,' Montero Quijano Leydi, ${ }^{2}$ Puga Chan Herbert ${ }^{3}$

'Orthopedic surgeon, Gral. Ignacio Zaragoza Hospital, Mexico ${ }^{2}$ Health Sciences Research, Yucat

${ }^{3}$ Department of Pediatric, Lic. Benito Juarez Hospital

Correspondence: Miguel Montero Quijano, Hospital Regional General Ignacio Zaragoza. Calzada Ignacio Zaragoza I7II, colonia Ejercito Constitucionalista, Mexico; Email drmiguelmonteroq@gmail.com

Received: July 24, 2017| Published: August 08, 2017

\section{Introduction}

The osteochondroma are the most common bone tumors representing 10 to $15 \%$ of the totality and there is the most common benign tumor on foot. ${ }^{1-3}$

The subungual osteochondroma itself as benign cartilage growths from the epiphyseal plate by endochondral growth. ${ }^{4}$ According to the World Health Organization it is defined as an osteochondral exostosis with continuity to bone marrow and cortical bone, they are more considered as an alteration of the development than a real tumor. ${ }^{5,6}$ Some studies consider the trauma and the radiation like a possible etiology of the osteochondroma. The dysfunction in the endochondral ossification allows the presence of residual cells of the epiphyseal plaque that have not taken part in the bony development, as a result they would proliferate and slowly increase its size to form the tumor. ${ }^{7}$

The first description of the subungual osteochondroma was documented in 1979 by Dr. Apfelberg. Subungual osteochondroma are benign tumors of the sub or periungual region, they provoke nail deformation, history of long, slow growth causing lift, ulceration and deformity at that level. ${ }^{8}$

The diagnosis is realized principally by clinic and the simple radiography in dorsopalmar and oblique projections, is usually enough for its diagnosis but the gold standard for the diagnosis is given by the histopathology study., ${ }^{9} 10$

The differential diagnosis are the chondroma, exostosis subungual and fibroma subungual which ones are the most common benign tumors in the subungual region. ${ }^{11}$ In the national literature there are few reports of this tumor, probably because it is underdiagnosed by not documenting the results of histopathology reports, this could explain its low incidence.

The subungual osteochondroma incidence in the pediatric population on this paper was taken from the General Ignacio Zaragoza Hospital in Mexico City's file room.

\section{Material and methods}

Descriptive, retrospective, and transversal study conducted in General Ignacio Zaragoza Hospital from January 2001 to March 2014 in the pediatric orthopedic service. We included all osteochondroma diagnosis by histopathology report, especially in region subungual, with a range of age from 0 to 18 years in the population of the west from the Mexico City.

\section{Results}

The diagnosis of osteochondroma was found in 47 histopathological studies results, 24 of them were found in low extremities, especially $7(14 \%)$ in the foot, the definitive diagnosis of subungual osteochondroma report 4 cases corresponding to $8.5 \%$ of all the osteochondroma o cases of subungual osteochondroma were reported in hands. The distribution by sex was $2(50 \%)$ for male and $2(50 \%)$ female, the patient's age range was from 6 to 12 years, whit an average of 9.5 years.

The locations ordered by frequency were, two cases (50\%) in the fourth finger, one case $(25 \%)$ in the second finger (Figures 1 \& 2) and one case $(25 \%)$ in first finger, all of them in the distal phalange (Figures $3 \& 4$ ). Right foot was more frequent with 3 cases, compared to only one case on the left foot. Only one patient performed a surgical intervention for symptomatology and development maturation. Only one patient underwent surgery to improve pain and demostrate adequate development of epiphyseal plaque.

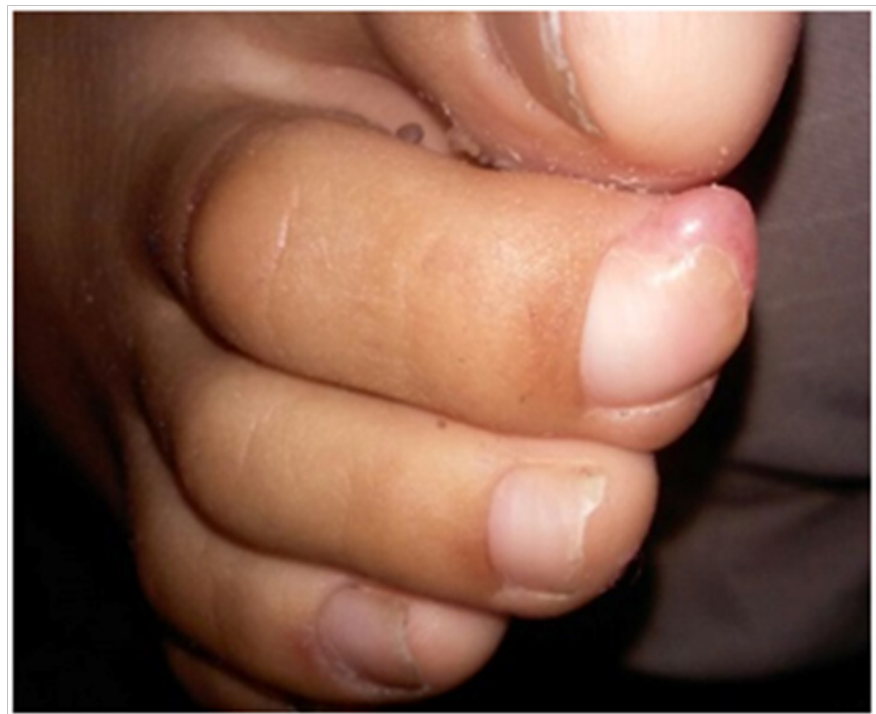

Figure I Subungual osteochondroma in the second distal phalanx. 


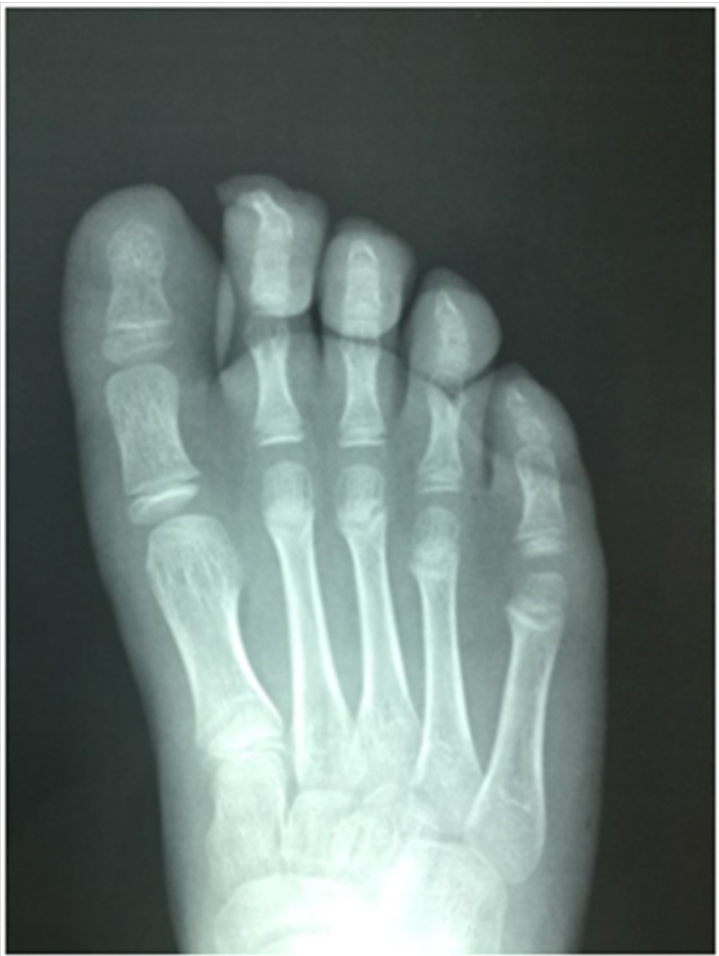

Figure 2 Dorsoplantar X-ray projection it's observed a pedunculated expansion of trabecular bone from the epiphyseal region of the second distal phalanx.

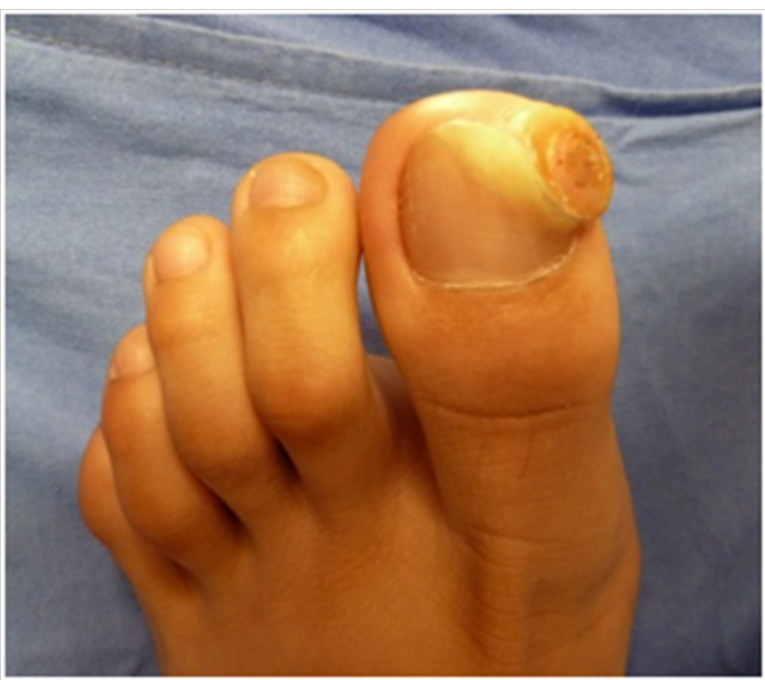

Figure 3 Subungual osteochondroma in the first distal phalanx.

\section{Discussion}

The osteochondroma are the most frequent benign bone tumor, and the foot has the biggest predominance..$^{12,13}$ The subungual osteochondroma presents an incidence of $8.5 \%$ between all the osteochondroma. Beard and cols, describes a female predominance with $70 \%$ of patients with subungual osteochondroma, 14 in other papers and articles evidence major predominance to the male 15 or equivalent numbers, in our investigation the relation was 1:1, without predominance sex. Lokiec and cols, report the frequency of subungual osteochondroma between the first and second decade of the life, coinciding with our report (mean: 9.5 year.)

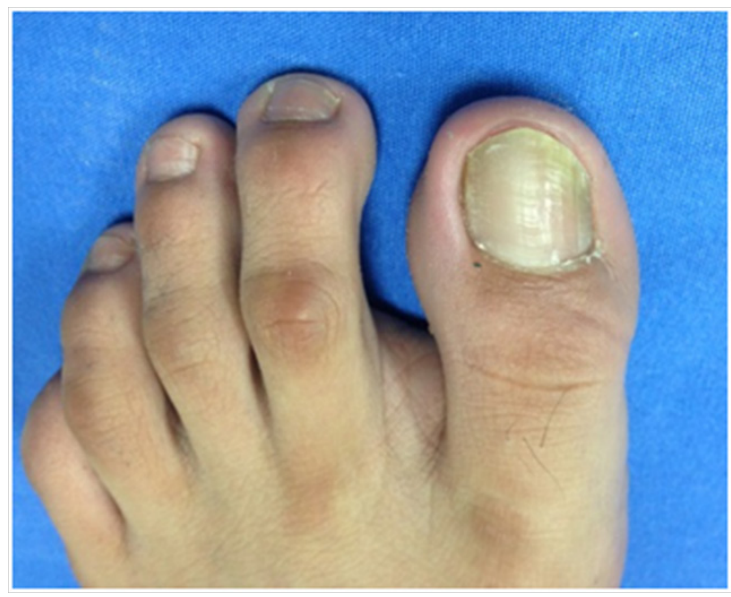

Figure 4 Evolution to the year of resection of Subungual osteochondroma in first distal phalanx.

Histologically, the osteochondroma is composed of hyaline cartilage with cells in a configuration similar to a normal growing epiphysis and the subungual exostosis revealed a base or stalk of normal appearing trabecular bone with a fibrocartilage cap.

The frequency in the foot was predominantly in fourth finger, continued in frequency in the first and second, compared to other reports where they reported the first toe like the most common presentation with approximately $80 \%$ of the cases. ${ }^{14-17}$

In the $\mathrm{x}$ ray projections, the Subungual osteochondroma is presented as a sessile image or pedunculated by the expansion of trabecular bone from the epiphyseal region of the distal phalanx and the subungual exostosis appeared as exophytic bony growth protruding from the dorsal surface of the tip of the distal phalanx in $\mathrm{X}$ - ray projections. ${ }^{18}$

It is common to confuse subungual exostosis with osteochondroma, although several authors have proposed it as a variant of osteochondroma, but they are considered as different pathologies. The definitive diagnosis will always be by histological report.

\section{Conclusion}

The results can be considered statistically insignificant to infer to other groups because of the number for report patients. This pathology has a low incidence; however, this paper reports the subungual osteochondroma as a single tumor, being a relevant fact to support of future studies to describe abnormalities in the bone growth in the foot. It is important the application of specific histological tests for a better differentiation between this pathology and subungual exostosis, which would increase the number of cases report and develop a better knowledge about Subungual Osteochondroma.

\section{Acknowledgments}

None.

\section{Conflicts of interest}

None.

\section{References}

1. Enneking WF, Conrad III EV Common bone tumors. In: Summit, (Ed.), Ciba Geigy, USA, p. 1983;2-45. 
2. Álvarez A. Yenima García Lorenzo, Eugenio Rodríguez Rodríguez et al. Comportamiento en diez años del osteocondroma en un hospital pediátrico. Rev Cubana Ortop Traumatol. 2002;16(1-2):61-64.

3. Tuzuner T, Kavak A, Parlak AH et al. Subungual osteochondroma: a diagnostic dilema. J Am Podiatr Med Assoc. 2006;96(2):154-157.

4. Richardson R Variants of Exostosis of the Bone in Children. Semin Roentgenol. 2005;40(4):380-390.

5. Murphey MD, Choi JJ, Kransdorf MJ et al. Imaging of osteochondroma: variants and complications with radiologic-pathologic correlation. $R a$ diographics. 2000;20(5):1407-1434.

6. Carpintero P, Del Fresno JA, Carpintero R et al. Complicaciones de los osteocondromas. Revista Española de Cirugía Osteoarticular. 2009;44(237):22-29.

7. Harper GD, Dicks-Mireaux C, Leiper AD Total body irradiation -induced osteochondromata. J Pediatr Orthop. 1998;18:356-358.

8. Rodriguez M, Minjares M, Hernandez M et al. Osteocondroma y exostosis subungueal. Características clínicoepidemiológicas e histológicas en pacientes mexicanos. Dermatol Rev Mex. 2012;56(4):236-240.

9. Kose O, Ertas A, Celiktas M et al. Fracture of an osteochondroma treated successfully with total excision: two case reports. Cases J. 2009;2:8062.

10. Martí J, Lladó M Osteocondroma en falange distal del primer dedo. Resolución quirúrgica a propósito de dos casos. Revista internacional de ciencias podológicas. 2010;4(2):21-28.
11. Norton L Nail disorders. J Am Acad Dermatol. 1980;2(6):451-467.

12. Mora-Ríos FG, Antonio-Romero CE, Mejía-Rohenes LC et al. Incidencia de pseudoartrosis en el Hospital Regional General Ignacio Zaragoza del ISSSTE. Rev Esp Med Quir. 2012;17(1):34-38.

13. Kline A Subungual Osteochondroma or Exostosis Cartilaginea of the Hallux: A case report of recurrent bone tumor one year later. The Foot and Ankle Online Journal. 2010;3(2):2.3

14. Rodriguez MA, Minjares LM, Hernandez MM et al. Osteocondroma y exostosis subungueal. Características clínicoepidemiológicas e histológicas en pacientes mexicanos. Dermatol Rev Mex. 2012;56(4):236-240.

15. Landon G, Johnson K, Dahlin D Subungual exostoses. J Bone Joint Surg Am. 1979;61(2):256-259.

16. Lokiec F, Ezra E, Krasin E et al. A simple and effiient surgical technique for subungueal exostosis. J Pediatr Orthop. 2001;21(1):76-79.

17. Davis D, Cohen P Subungual exostosis: Case report and review of the literature. Pediatr Dermatol. 1996;13(3):212-218.

18. Murphey MD, Choi JJ, Kransdorf MJ et al. Imaging of osteochondroma: variants and complication with radiologic-pathologic correlation. $R a$ diographics. 2000;20:1407-1434. 